\title{
5
}

\section{Konsep Diri Anak Jalanan :}

Kasus Anak Jalanan di Kota Bogor Provinsi Jawa Barat

Yunda Pamuchtia dan Nurmala K. Pandjaitan

\begin{abstract}
ABSTRAK
Penelitian ini mengenai konsep diri anak jalanan untuk dapat memahami tingkah laku mereka. Tujuan penelitian ini adalah untuk mengetahui: (1) Karakteristik sosial ekonomi anak jalanan, (2) Konsep diri anak jalanan, (3) Perbedaan konsep diri berdasarkan karakteristik anak jalanan. Mayoritas anak jalanan di ketiga lokasi penelitian adalah lakilaki dengan tingkat pendidikan rendah (rata-rata hanya tamat Sekolah Dasar). Sebagian besar anak jalanan bekerja sebagai pengamen. Alasan anak jalanan bekerja sebagian adalah karena kesulitan ekonomi dan sebagian lagi untuk mencari uang tambahan dan untuk rekreasi. Pendidikan orang tua anak jalanan rata-rata hanya tamat Sekolah Dasar dan bekerja di sektor marjinal seperti buruh dan pada bidang jasa seperti tukang ojek dan membuka bengkel. Konsep diri anak jalanan menyangkut karakter pribadi, penampilan fisik, hubungan dengan orang tua, umum, sikap jujur dan percaya dan hubungan dengan Tuhan ternyata cenderung positif. Artinya sebagian besar anak jalanan melihat dirinya cenderung positif. Namun konsep diri menyangkut kestabilan emosi yang dimiliki anak jalanan cenderung sedang, anak jalanan mengakui kondisi mereka sering labil. Ada perbedaan antara konsep diri anak jalanan berdasarkan karakteristik sosial ekonomi yang mereka miliki seperti usia, jenis kelamin dan alasan turun ke jalan, namun tidak ada perbedaan konsep diri berdasarkan tingkat pendidikan dan jenis pekerjaan. Konsep diri anak jalanan cenderung positif ternyata belum muncul dalam usaha mereka untuk memperbaiki diri dalam memilih pekerjaan dan berhubungan dengan orang lain yang tidak bekerja sebagai anak jalanan ataupun orang lain yang tidak senasib dengan mereka.
\end{abstract}

Keyword: street children, self concept

\section{PENDAHULUAN}

Isu kesejahteraan anak terus mendapat perhatian masyarakat dunia. Mulai dari permasalahan buruh anak, peradilan anak, pelecehan seksual pada anak, dan anak jalanan. Data Yayasan Gerbong Rakyat, anak jalanan di kota Bogor pada tahun 2003 berjumlah 400 jiwa. Jumlah ini meningkat kurang lebih sebesar 50 persen dari tahun sebelumnya (Anonim, 2003). Ketua Komisi Nasional Perlindungan Anak Seto Mulyadi mengatakan jumlah anak jalanan pada tahun 2008 di wilayah Jabodetabek mencapai 80 ribu anak dengan 30 ribu anak berada di wilayah Jakarta (Moeko, 2008). Hal ini memperlihatkan jumlah anak jalanan yang terus meningkat tiap tahunnya. Penelitian ini dilakukan memiliki arti cukup penting karena permasalahannya, jumlah anak jalanan yang terus meningkat ini masih ditangani 
secara terbatas. Studi-studi yang ada sebelumnya masih terbatas pada pembahasan mengenai karakteristik sosial ekonomi, pembinaan rumah singgah dan tingkat kekerasan yang dialami anak jalanan saja dan belum melihat anak jalanan dari sudut psikologi sosial yaitu dengan memahami konsep diri anak jalanan. Konsep diri anak jalanan perlu dipahami karena konsep diri mempunyai pengaruh yang besar terhadap keseluruhan perilaku yang ditampilkan seseorang (Muslim dan Mardiyati, 2004). Dengan memahami perbedaan konsep diri anak jalanan berdasarkan karakteristik mereka maka pembinaan anak jalanan akan tepat sasaran sesuai dengan konsep diri anak jalanan. Berdasarkan latar belakang tersebut permasalahan yang akan dikaji adalah (1) Bagaimana karakteristik sosial dan ekonomi Anak Jalanan? (2) Bagaimana konsep diri yang terbentuk pada anak jalanan? (3) Bagaimana perbedaan konsep diri anak jalanan berdasarkan karakteristik sosial ekonomi anak jalanan?

\section{KERANGKA PEMIKIRAN}

Konsep diri merupakan faktor yang penting bagi pembentukan tingkah laku manusia. Manfaat individu mengetahui konsep diri adalah mereka dapat menampilkan perilaku yang diterima dari respon-respon dan pandangan-pandangan yang diberikan oleh orang lain. Terkait dengan anak jalanan, konsep diri adalah gambaran yang dimiliki oleh seorang anak jalanan tentang dirinya. Hal ini merupakan apa yang diyakini anak jalanan pada dirinya, meliputi karakteristik fisik, psikologi, sosial, dan emosional serta aspirasi-aspirasi dan prestasinya. Gambaran yang dimiliki anak jalanan ini adalah penilaian dari segala hal yang mereka ketahui, rasakan dan mereka yakini ada pada diri mereka, meliputi karakteristik diri dan bagaimana mereka berhubungan dengan dunia luar, yang berkembang berdasarkan hasil persepsi dari orang lain dan diri mereka sendiri.

Cara seseorang memandang dan menilai dirinya, menurut para ahli psikologi memiliki kaitan dengan perilaku dengan yang ditampilkannya. Orang yang menilai dirinya sebagai tidak baik (konsep diri negatif), cenderung menarik diri dalam berhubungan dengan orang lain, atau bertindak agresif secara tidak wajar. Jika seorang anak jalanan berpikir bahwa dirinya bodoh, ia akan merasa tak sanggup melaksanakan tugas-tugas yang dipandangnya tugas "orang-orang pintar". Bila seorang anak jalanan merasa dirinya memiliki kemampuan mengatasi masalah, maka persoalan apapun yang dihadapinya pada akhirnya cenderung dapat diatasi. Bila seorang anak jalanan merasa dirinya tampan dan ketampanan itu merupakan bagian penting dalam melaksanakan pekerjaannya, ia akan tampil percaya diri dan bertindak positif. Burns, seorang ahli psikologi yang secara khusus mempelajari ihwal konsep diri dengan perilaku, mengisyaratkan bahwa konsep diri secara potensial memiliki kaitan dengan bagian-bagian yang amat luas dari perilaku manusia (Burns, 1993).

Karakteristik anak jalanan yang terdiri dari faktor internal dan faktor eksternal diduga dapat mempengaruhi konsep diri anak jalanan. Faktor internal dalam karakteristik sosial ekonomi anak jalanan ini terdiri dari usia, jenis kelamin, tingkat pendidikan, jenis pekerjaan dan alasan turun ke jalan. Faktor internal anak jalanan ini akan dilihat hubungannya dengan konsep diri yang terbentuk pada anak jalanan. Hal ini dapat disederhanakan melalui gambar kerangka pemikiran (Gambar 1). Sedangkan faktor eksternal yang terdiri dari tingkat kekerasan yang diterima anak 
jalanan dan tingkat sosial ekonomi tidak dimasukan ke dalam ruang lingkup penelitian.

\section{Karakteristik Sosial Ekonomi Anak Jalanan}

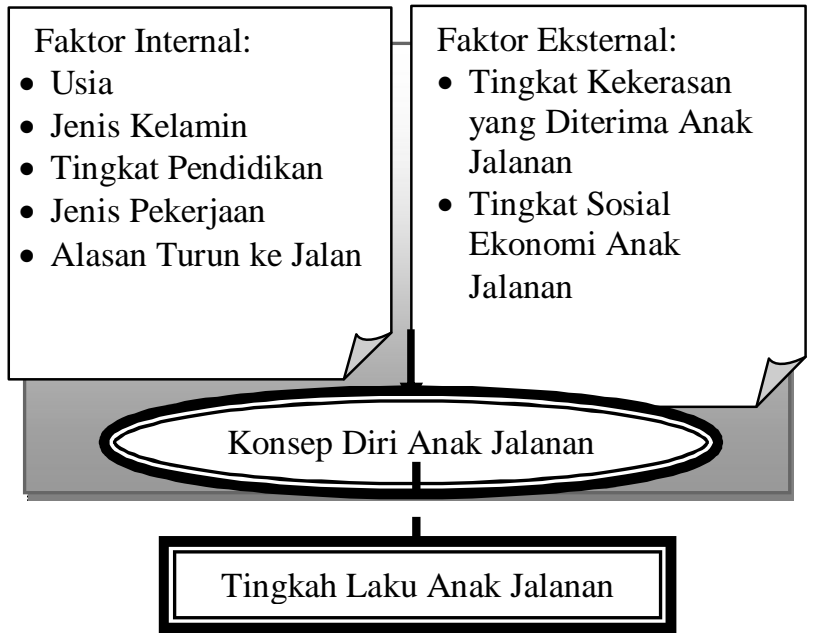

Gambar 1. Kerangka Pemikiran Operasional

\section{Keterangan:}

\section{HIPOTESIS \\ 1. Diduga konsep diri anak jalanan berbeda berdasarkan karakteristik sosial ekonomi anak jalanan.}

\section{METODOLOGI}

Penelitian ini dilaksanakan Kota Bogor, Provinsi Jawa Barat tepatnya di Jl. Sholeh Iskandar di depan pusat perbelanjaan Hypermart, pertigaan rel kereta api di Kebon Pedes, di pertigaan lampu merah Jl. Baru dan perempatan lampu merah Hotel Pangrango 2. Lokasi-lokasi ini didapatkan dari informan yang bekerja di Rumah Singgah Yayasan Titian Mandiri. Jumlah responden yang diambil adalah minimal 30 orang. Angka 30 diambil dari standar minimal penelitian survei (Singarimbun dan Effendi, 1989). Responden sejumlah 30 orang diambil dengan menggunakan teknik accidential sampling. Teknik pengolahan dan analisis data pada penelitian ini menggunakan tabulasi silang untuk memperoleh presentase. konsep diri dihitung dengan menggunakan skala Likert yang terdiri dari lima kategori jawaban. Setiap alternatif diberikan jawaban skor 5 sebagai skor tertinggi sampai dengan skor 1 sebagai nilai terendah. Skor 5 berarti sangat setuju, sedangkan skor terendah adalah sangat tidak setuju. Maka skor total tertinggi dari konsep diri adalah 5 x $42=210$ dan skor total terendah adalah 42. Guna kepentingan analisis, untuk mengetahui jawaban responden dari kuesioner per variabel dilakukan dengan membagi skor total ke dalam tiga range yaitu positif, sedang dan negatif. 


\section{HASIL DAN PEMBAHASAN}

\section{Karakteristik Anak Jalanan}

Gambar 2. Jumlah Responden Berdasarkan Usia dan Jenis Kelamin

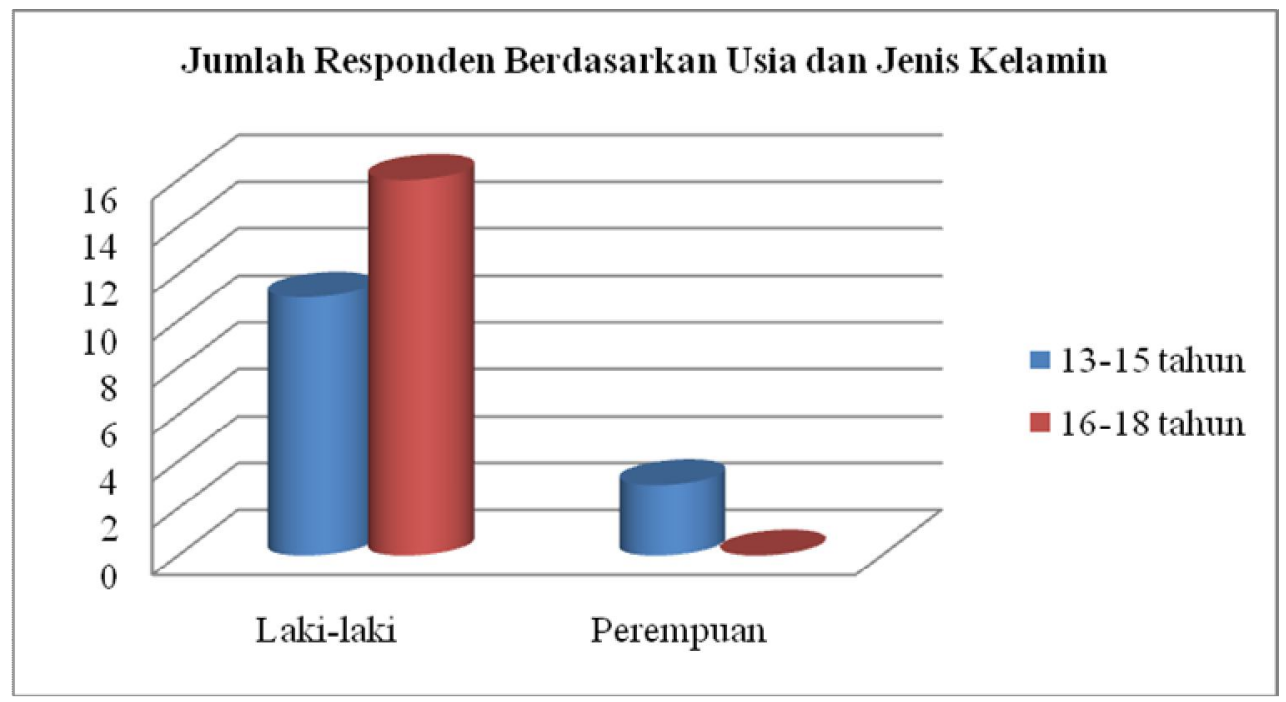

Berdasarkan Gambar 2 dapat dilihat bahwa sebagian besar anak jalanan yang menjadi responden adalah anak laki-laki. Hal ini seperti informasi yang dikatakan BDN (40 tahun) bahwa dulu memang banyak anak jalanan perempuan. Namun, sekarang anak jalanan perempuan sudah jarang ditemukan di jalanan karena mereka sudah besar sehingga mereka sudah merasa malu bekerja sebagai anak jalanan lagi. Hal ini mengindikasikan bahwa anak jalanan perempuan mempunyai faktor rasa malu yang lebih besar dibandingkan anak jalanan laki-laki. Anak jalanan yang dijadikan responden dibagi menjadi dua kategori usia yaitu 13 sampai 15 tahun dan 16 sampai 18 tahun. Jumlah anak jalanan yang berusia 16 sampai 18 tahun lebih besar daripada yang berusia 13 sampai 15 tahun. Namun jumlah anak perempuan lebih banyak pada anak jalanan yang berusia 13 sampai 15 tahun.

Tingkat pendidikan anak jalanan ternyata sebagian besar di Sekolah Dasar dan Sekolah Menengah Pertama, diantara yang berpendidikan Sekolah Dasar dan Sekolah Menengah Pertama tersebut ada yang tidak menamatkan sekolahnya (Gambar 3). Pada umumnya mereka tidak melanjutkan sekolah karena keterbatasan ekonomi. Selain itu ada juga anak jalanan yang tidak ingin melanjutkan sekolah karena malu. MHG (10 tahun) tidak mau bersekolah karena tidak bisa membaca walaupun sudah belajar berkali-kali. Padahal MHG tidak perlu memikirkan biaya untuk sekolahnya lagi karena ia mendapat bantuan dari seorang donatur.

Diantara yang tidak tamat SD, terdapat responden perempuan berinisial ENG (13 tahun). ENG tidak sekolah lagi karena tidak ada biaya, akhirnya ia diajak oleh ketua Yayasan Titian Mandiri untuk mengikuti Paket A di yayasan yang dekat dengan lokasi mengamen ENG. Pada awalnya ENG mau mengikuti kegiatan tersebut, namun pada akhirnya ia berhenti karena malu karena anak-anak yang mengikuti Paket A usianya lebih muda dari ENG. 


\section{Jumlah Responden Berdasarkan Tingkat Pendidikan dan Jenis Pekerjaan}

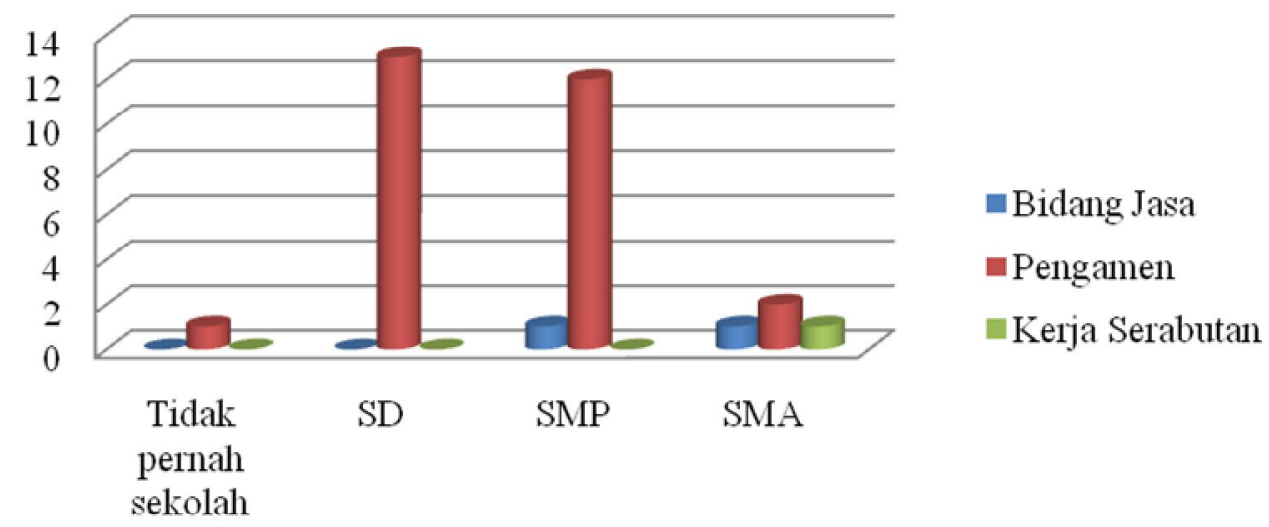

Gambar 3. Jumlah Responden Berdasarkan Tingkat Pendidikan dan Jenis Pekerjaan

Responden yang telah lulus Sekolah Menengah Atas hanya satu orang yaitu MWN (18 tahun). MWN berasal dari keluarga yang sederhana, Ayahnya bekerja sebagai staf Tata Usaha di sebuah universitas swasta di daerah Bogor dan kakaknya kini sedang berkuliah di tempat ayahnya bekerja. Ia tidak ingin melanjutkan sekolah ke jenjang yang lebih tinggi karena ingin belajar mandiri dengan bekerja (tidak membebani orang tua) dalam hal uang saku. Ketiga kasus di atas memperlihatkan bahwa tidak berlanjutnya pendidikan anak jalanan bukan hanya faktor biaya tetapi juga faktor lainnya seperti usia, kesulitan ekonomi, dan ketidaktertarikan terhadap pendidikan.

Jenis pekerjaan yang dominan dilakukan anak jalanan adalah pengamen (93.33\%). Responden yang bekerja di bidang jasa (3.33\%) adalah responden yang bekerja sebagai calo angkutan umum nomor 32 setelah pulang sekolah. Sedangkan responden yang mempunyai jenis pekerjaan serabutan (3.33\%) adalah responden yang tidak memiliki pekerjaan yang pasti atau bisa disebut bekerja secara musiman.

Pengamen ini pada umumnya berpendidikan Sekolah Dasar dan Sekolah Menengah Pertama. Responden yang melakukan pekerjaan di bidang jasa dan pekerjaan serabutan mempunyai pendidikan terakhir Sekolah Menengah Pertama dan Sekolah Menengah Atas. Usia mereka rata-rata 17 tahun. Hal ini memperlihatkan bahwa responden yang bekerja sebagai pengamen umumnya masih muda dan masih ingin bersenang-senang dalam melakukan pekerjaan tersebut. Mereka berpikir dengan bekerja sebagai pengamen mereka bisa istirahat semaunya. Lain halnya dengan responden yang bekerja sebagai calo atau buruh bangunan pada umumnya harus mempunyai kekuatan fisik yang relatif besar.

Sebagian besar anak jalanan mempunyai alasan turun ke jalan karena kesulitan ekonomi sedangkan alasan anak turun ke jalan yang kedua adalah untuk mencari tambahan uang saku. Anak jalanan yang turun ke jalan dengan alasan kedua ini biasanya turun ke jalan jika mereka perlu uang untuk membeli sesuatu. Alasan yang ketiga adalah rekreasi. Alasan rekreasi adalah anak jalanan turun ke jalan karena 
hanya ingin bermain dengan teman-temannya saja dan untuk menyalurkan kegemaran mereka terhadap musik. Sedangkan alasan anak turun ke jalan karena kurang perhatian keluarga tidak ditemukan pada 30 responden tersebut.

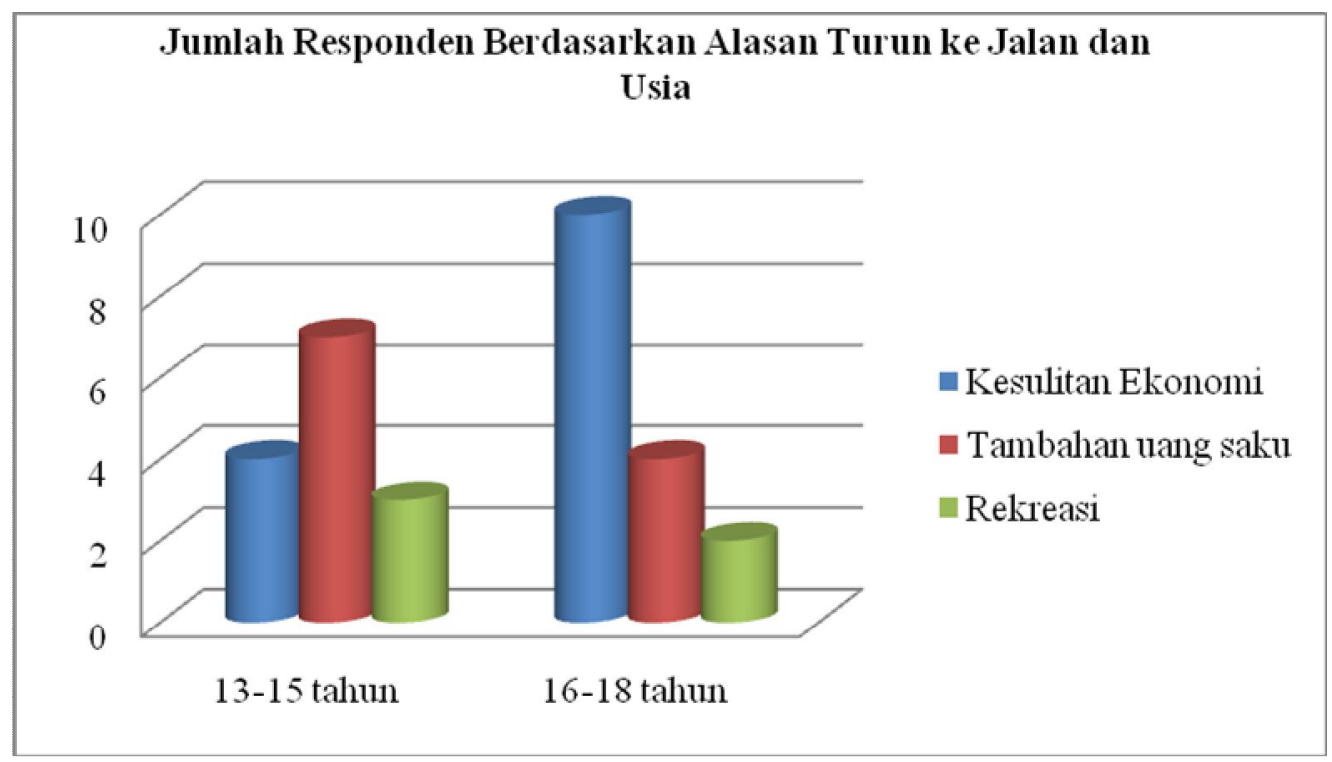

Gambar 4. Jumlah Responden Berdasarkan Alasan Turun ke Jalan dan Usia

Rata-rata pendidikan terakhir orang tua anak jalanan hanya tamat Sekolah Dasar (Gambar 5). Hal ini menunjukkan bahwa tidak mengherankan anak jalanan juga tidak memiliki tingkat pendidikan yang tinggi atau hanya sebatas Sekolah Dasar saja. Selain dikarenakan faktor kesulitan ekonomi, orang tua mereka juga tidak menyadari pentingnya arti pendidikan.

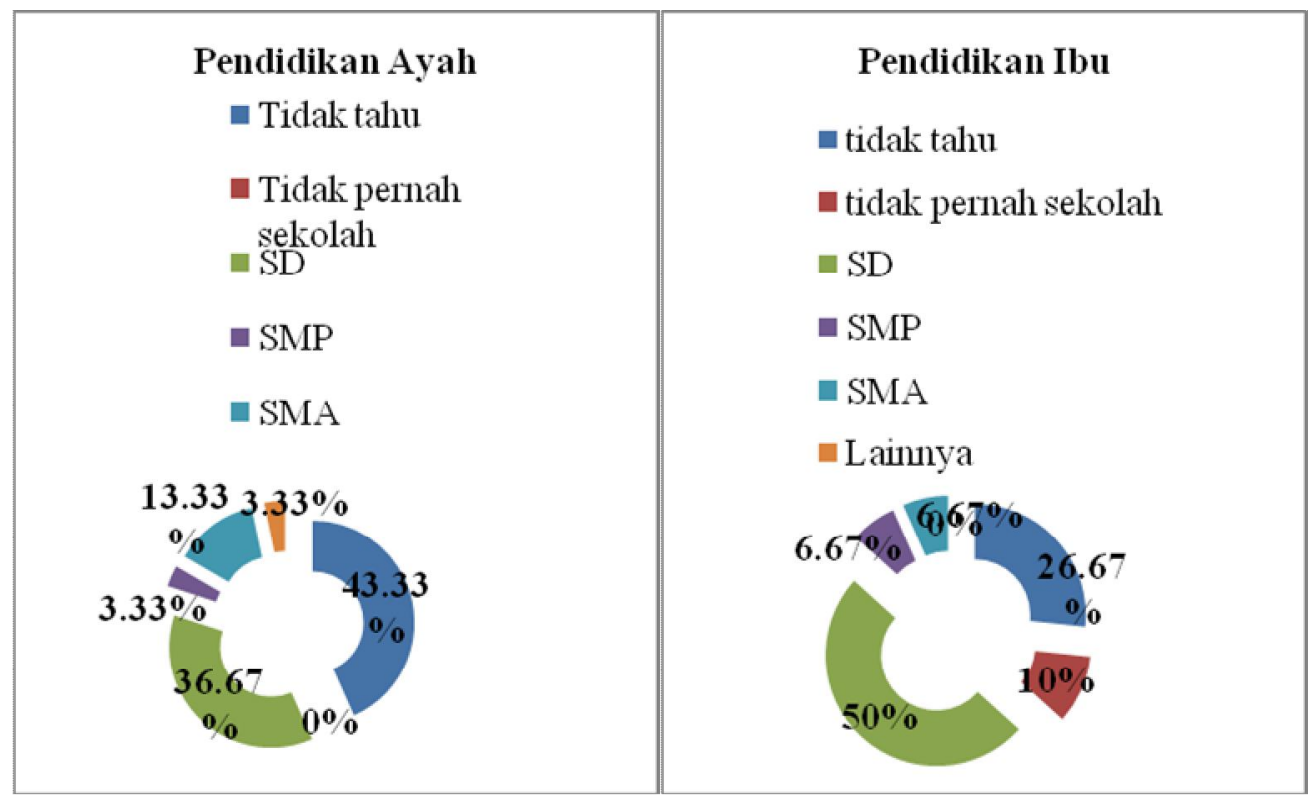

Gambar 5. Jumlah Responden Berdasarkan Tingkat Pendidikan Akhir Orang Tua 
Seperti umumnya pendidikan orang tua yang tidak mampu yaitu sebagian besar hanya tamat Sekolah Dasar, tidak mengherankan pekerjaan orang tua mereka di sektor marjinal. Namun, ada juga orang tua anak jalanan yang bekerja di sektor formal seperti (lainnya) dosen dan pegawai swasta.
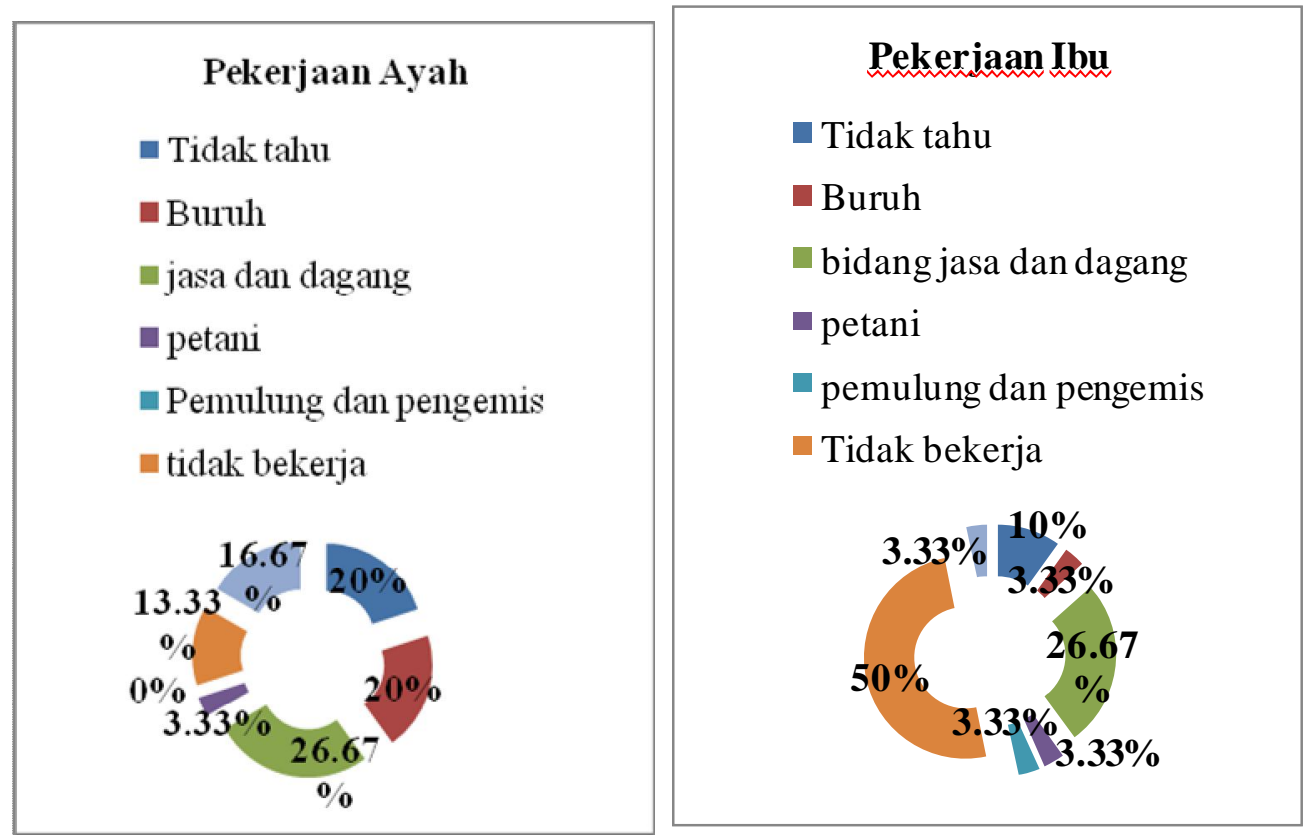

Gambar 6. Jumlah Responden Berdasarkan Jenis Pekerjaan Orang Tua

Penghasilan orang tua seringkali dikaitkan dengan tingkat kesejahteraan suatu keluarga. Sayangnya sebesar 60 persen responden tidak mengetahui jumlah penghasilan ayah mereka dan sebagian besar (50\%) ibu responden tidak mempunyai penghasilan atau sebagai ibu rumah tangga. Dari Gambar 5, 6, 7 dapat disimpulkan rata-rata anak jalanan tergolong miskin dengan kiteria menurut BPS yaitu pendapatan di bawah Rp. 600.000,00 per bulan dan pendidikan tertinggi kepala rumah tangga hanya sampai Sekolah Dasar.

Kehidupan anak jalanan sering diidentikkan dengan kehidupan yang keras. Namun pada kenyataannya berdasarkan Gambar 8 dapat dilihat sebagian besar anak jalanan (60\%) tidak pernah mengalami tingkat kekerasan. Walaupun beberapa dari mereka pernah dimintai uang atau rokok oleh pengamen lain yang lebih dewasa, tetapi mereka tidak menganggap itu pemalakan melainkan hanya sekedar memperkuat solidaritas pertemanan antar sesama pengamen dan memperluas pergaulan. 

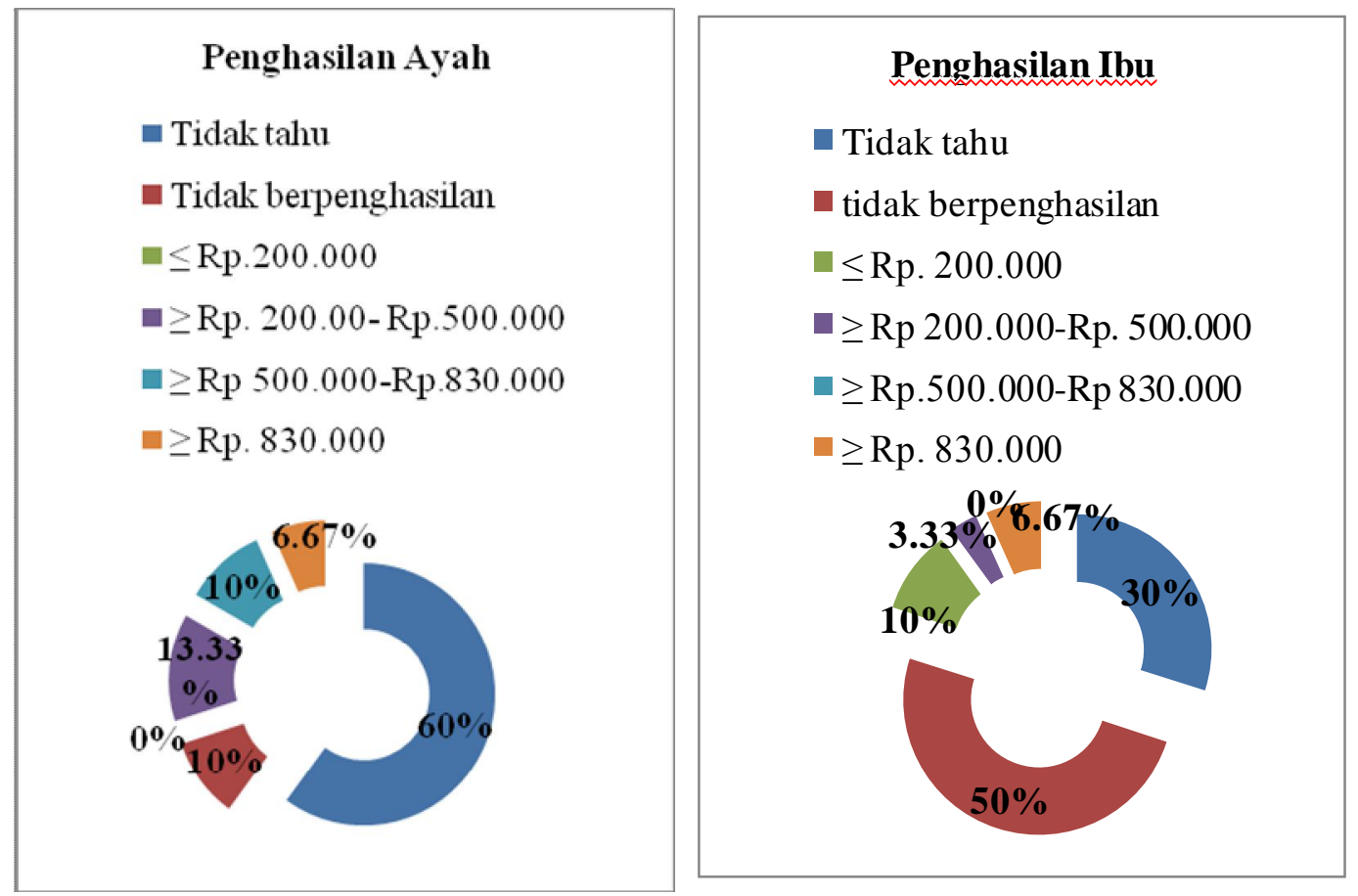

Gambar 7. Jumlah Responden Berdasarkan Penghasilan Orang Tua

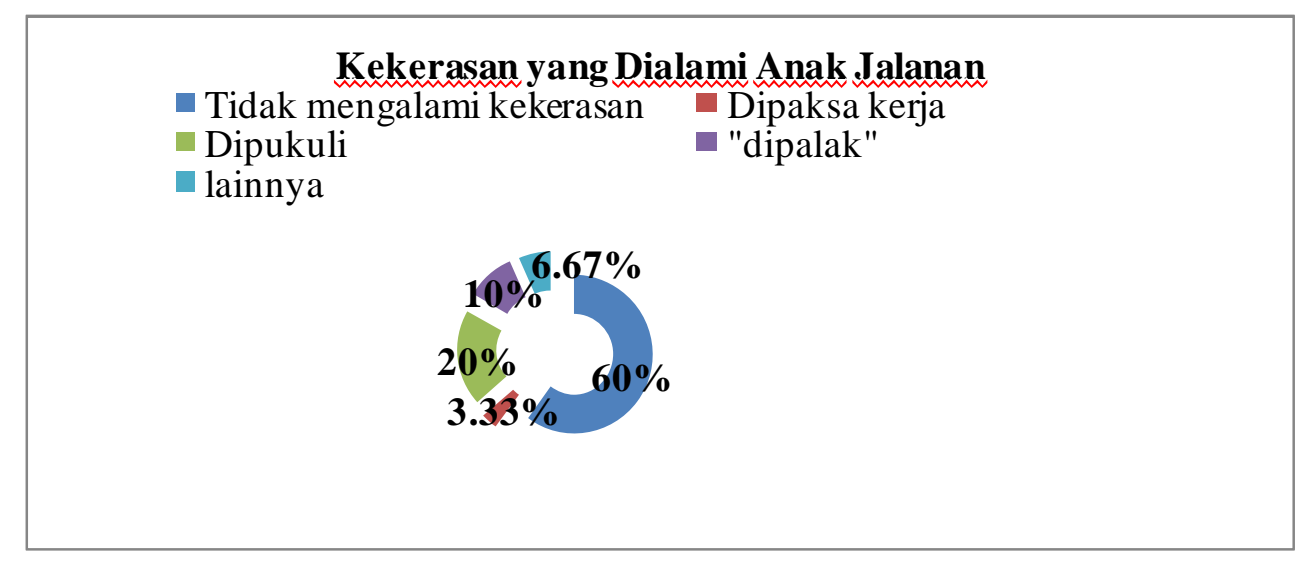

Gambar 9. Jumlah Responden Berdasarkan Kekerasan yang Dialami Anak Jalanan.

\section{Konsep Diri}

Konsep diri terhadap karakter diri adalah konsep diri yang berkaitan dengan cara pandang anak jalanan terhadap karakter dirinya sendiri. Berdasarkan hasil penelitian, rataan skor mengenai konsep diri terhadap karakter pribadi responden sebesar 34.3 yaitu cenderung positif (Gambar 10).

Responden yang mempunyai konsep diri yang cenderung positif menganggap diri mereka pekerja keras, mandiri, kreatif dan tegar. SYF (17 tahun) mengatakan bahwa dengan bekerja sebagai pengamen, mereka sama saja dengan orang lain yang bekerja 
di kantor. Bahkan menurutnya, orang yang bekerja di kantor lebih nyaman karena tidak perlu terkena panas matahari ketika bekerja, berbeda halnya dengan pekerjaan sebagai pengamen. Dalam hal kreatif, SYR (18 tahun) mengatakan bahwa dia kreatif karena jika dia sedang bosan dia bisa mendapat inspirasi untuk membuat lagu. Responden merasa mandiri karena mereka merasa sudah bisa menghasilkan uang untuk hidup mereka. Mereka tidak perlu lagi meminta uang kepada orang tua untuk jajan atau makan sehari-hari. Bahkan ada diantara mereka yang memberikan uang yang didapat dari hasil mengamen kepada keluarga mereka.

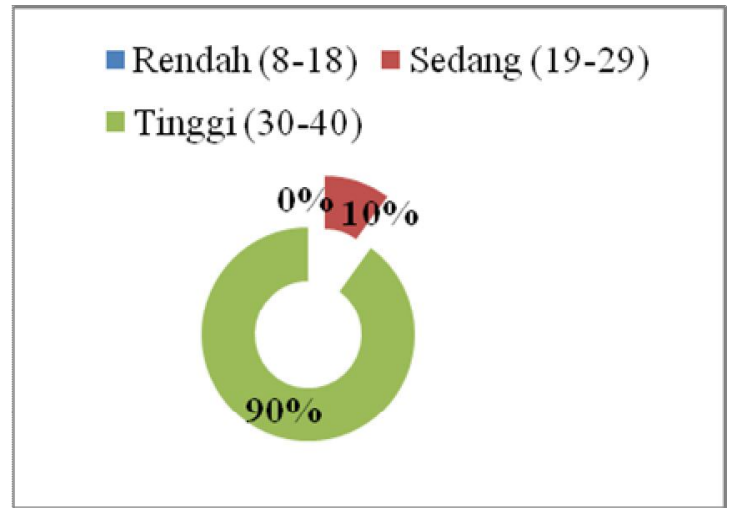

Gambar 10. Jumlah Responden Berdasarkan Konsep Diri Karakter Pribadi

Responden yang memiliki konsep diri cenderung sedang, walaupun mereka menganggap diri mereka pekerja keras, mandiri dan tegar tetapi mereka tidak kreatif. Selain itu menurut PLY (17 tahun), dia merasa bahwa dirinya adalah pemberontak. Dia mengatakan demikian karena dia ikut bergabung dalam kelompok punk dengan alasan bahwa kelompok ini mengkritik pemerintah Indonesia yang sering korupsi.

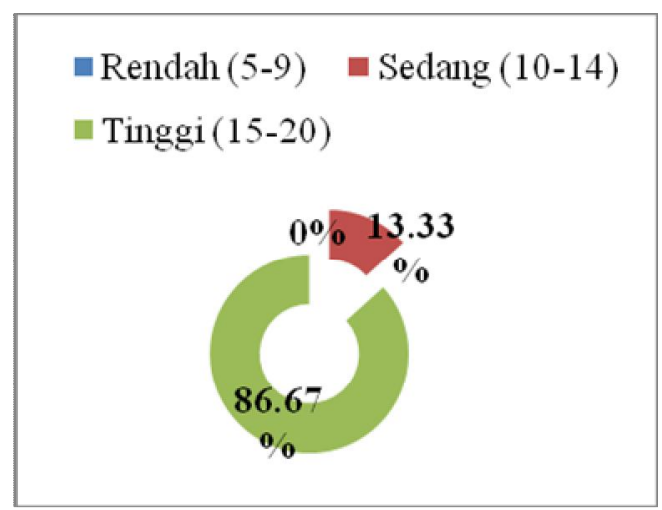

Gambar 11. Jumlah Responden Berdasarkan Konsep Diri Penampilan Fisik

Berdasarkan hasil penelitian rataan skor mengenai konsep diri terhadap karakter responden sebesar 17.13 yaitu cenderung positif (Gambar 11). Anak jalanan menganggap penampilan fisik mereka menarik dan tidak membenci penampilan mereka sebagai anak jalanan. Dilihat dari pengamatan, walaupun badan atau fisik mereka kotor atau dekil tetapi mereka masih memakai pakaian yang layak. Bahkan ada juga anak jalanan yang termasuk ke dalam kelompok punk yang menambahkan 
aksesoris, seperti kalung, anting dan gelang pada penampilan mereka. Tidak jarang juga responden yang mengamen dengan memakai sepatu.

Responden yang memiliki konsep diri penampilan fisik cenderung sedang merasa bahwa penampilan mereka lebih baik dari teman mereka yang lain. Berdasarkan wawancara dengan END (18 tahun) yaitu dia merasa minder ketika berkenalan dengan teman-teman yang bukan pengamen khususnya perempuan ketika dia sedang berkumpul dengan teman-temannya di depan supermarket Circle $K$ di Jl. Ahmad Yani. Hal ini disebabkan dia merasa bahwa wajahnya tidak menarik. Selain itu, ENG (13 tahun) juga mengatakan bahwa dirinya jelek karena kulitnya yang berwarna hitam akibat bekerja di jalanan.

Hubungan responden dengan orang tua, sebanyak 63.33 persen (Gambar 12) responden mempunyai konsep diri hubungan dengan orang tua yang cenderung positif. Walaupun responden ikut mencari nafkah di jalanan karena ketidakmampuan orang tua mereka dalam segi ekonomi tetapi mereka masih mencintai dan merasa dicintai oleh orang tua mereka. SYR (17 tahun) mengatakan bahwa dia tidak merasa sulit ketika mengobrol dengan kedua orang tuanya. Biasanya dia bersama kedua orang tuanya mengobrol setelah dia pulang mengamen pada waktu malam hari. Halhal yang dibicarakan pun bermacam-macam, dari masalah keluarga sampai keadaan di jalanan ketika dia sedang mengamen.

Responden yang memiliki konsep diri cenderung sedang merasa bahwa orang tua mereka seringkali merasa kecewa dengan yang mereka kerjakan di jalanan. Hal ini disebabkan kebanyakan dari anak jalanan mengatakan bahwa mereka tidak diijinkan bekerja di jalanan oleh orang tua mereka.

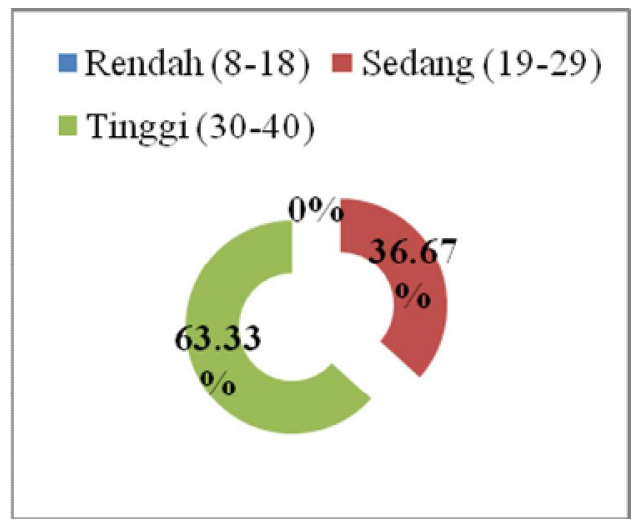

Gambar 12. Jumlah Responden Berdasarkan Konsep Diri Hubungan dengan Orang Tua

Berdasarkan Gambar 13 sebanyak 76.66 persen responden mempunyai konsep diri kestabilan emosi cenderung sedang dengan skor 19.73. Hal ini menunjukkan bahwa sebagian besar responden tidak bisa mengelola emosi mereka dengan baik. Hal ini ditunjukkan dari beberapa responden yang sering berkelahi dengan teman sesama pengamen yang lain.

Ketidakstabilan emosi yang dialami anak jalanan juga merupakan akibat dari faktor lain yaitu konsumsi mereka terhadap narkoba. Hal ini seperti yang dikatakan oleh SYF (17 tahun) yaitu dia mengkonsumsi pil Leksotan ketika ingin mengamen. Dia 
mengkonsumsi pil tersebut agar dia bisa tetap semangat dan tidak malu ketika mengamen di angkutan umum. Perkelahian yang timbul dengan supir angkutan umumpun terjadi ketika dia tidak sadar akibat mengkonsumsi pil Leksotan tersebut. Dia mengatakan ketika mengkonsumsi pil tersebut dia menjadi lebih berani kepada orang lain.

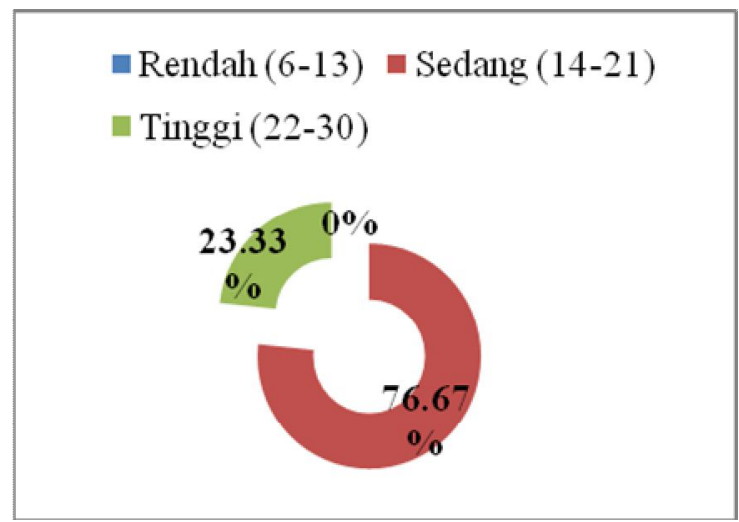

Gambar 13. Jumlah Responden Berdasarkan Konsep Diri Kestabilan Emosi

Berdasarkan Gambar 14 sebesar 53.33 persen responden mempunyai konsep diri umum yang cenderung positif dengan skor 21.8. Namun perbedaan jumlah antara responden yang mempunyai konsep diri umum yang cenderung tinggi dan sedang hanya sedikit berbeda. Hal ini mengindikasikan bahwa anak jalanan menghargai diri mereka sendiri dan bisa membangun rasa percaya diri. Namun, walaupun rata-rata anak jalanan merasa bangga pada diri mereka, masih ada juga yang sedikit merasa bahwa dia tidak mempunyai hal yang pantas untuk dibanggakan. Berdasarkan wawancara dengan responden MWN (17 tahun), dia merasa bangga jika turun ke jalan dan bisa menghasilkan uang untuk dirinya sendiri tanpa harus meminta uang dari orang tua.

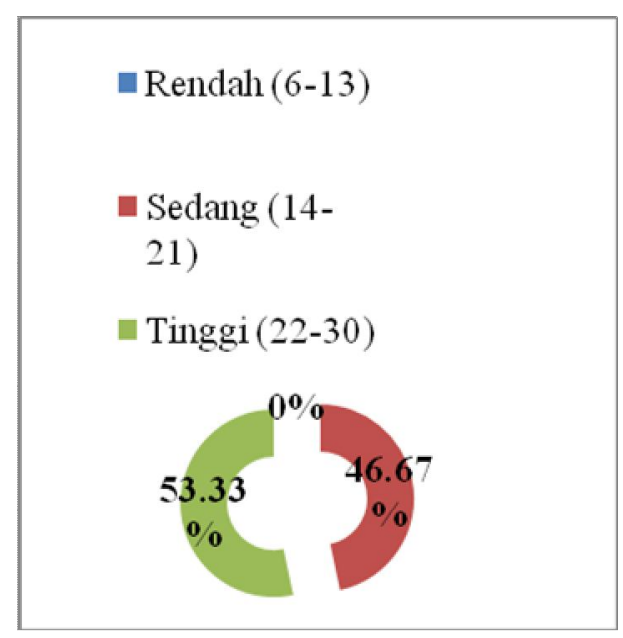

Gambar 14. Jumlah Responden Berdasarkan Konsep Diri Umum 
Berdasarkan Gambar 15 sebanyak 96.66 persen responden mempunyai konsep diri terhadap sikap jujur yang cenderung positif dengan skor 18.6. Respoden menganggap kejujuran merupakan hal yang penting dan mereka jujur dalam memahami kelebihan dan kekurangan yang dimilikinya. Hal ini terlihat ketika melakukan wawancara, mereka tidak malu untuk menceritakan hal-hal negatif atau kekurangan pada dirinya seperti pemakaian narkoba, seks bebas dan minuman keras.

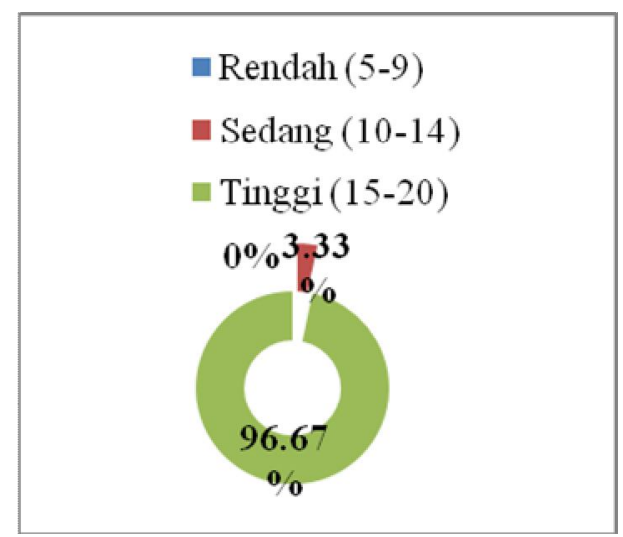

Gambar 15. Jumlah Responden Berdasarkan Konsep Diri terhadap Sikap Jujur dan Percaya

Berdasarkan Gambar 16 sebanyak 70 persen responden mempunyai konsep diri terhadap hubungan dengan Tuhan yang cenderung positif dengan skor 14.53. Anak jalanan merasa bahwa Tuhan masih mencintai mereka walaupun hidup mereka tidak mampu. Mereka juga tidak menganggap diri mereka hina dan menganggap pekerjaan mereka sebagai anak jalanan adalah pekerjaan yang halal. Namun dalam mengerjakan ibadah, mereka jarang melaksanakannya.

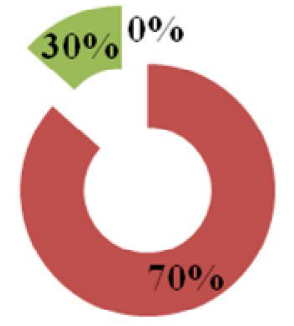

Rendah (4-8)

- Sedang $(9-13)$

- Tinggi (14-20)

Gambar 16. Jumlah Responden Berdasarkan Konsep Diri Hubungan dengan Tuhan

Seorang anak jalanan perempuan UPH (14 tahun) mengatakan bahwa dia mengikuti pengajian di mesjid dekat rumahnya. Namun dalam kesehariannya dia jarang melaksanakan ibadah sholat karena tempat dia mengamen dan beristirahat pada waktu siang hari jauh dari tempat peribadatan. Lain halnya dengan SYR (17 tahun) yang juga mengatakan bahwa dia malas menjalankan ibadah. Hal ini bukan dikarenakan tidak adanya tempat peribadatan tetapi dia merasa ribet jika harus mengerjakan ibadah di saat bekerja. 
Beberapa aspek konsep diri yang telah dijabarkan sebelumnya akan dihubungkan dengan karakteristik sosial ekonomi anak jalanan seperti usia, jenis kelamin, jenis pekerjaan, tingkat pendidikan dan alasan turun ke jalan. Berdasarkan Gambar 17 dapat dilihat terdapat perbedaan konsep diri berdasarkan usia responden. Konsep diri positif lebih menonjol pada yang berusia 13 sampai 15 tahun $(85.71 \%)$ daripada yang berusia 16 sampai 18 tahun (43.75\%). Hal ini mengindikasikan bahwa responden yang berusia di bawah 16 tahun bangga terhadap dirinya sendiri. Mereka tidak merasa rendah diri dengan pekerjaan mereka sebagai pengamen karena kebanyakan anak jalanan usia 13 sampai 15 tahun turun ke jalan hanya untuk tambahan uang saku ataupun rekreasi dengan teman-teman mereka. Mereka merasa bangga karena pada usia ini mereka sudah tidak perlu lagi meminta uang saku dari orang tuanya.

Perbedaan konsep diri anak jalanan menurut usia ini berkaitan dengan alasan mereka turun ke jalan. kebanyakan responden yang berusia 16 sampai 18 tahun turun ke jalan karena kesulitan ekonomi, sedangkan responden yang berusia 13 sampai 15 tahun turun ke jalan adalah untuk mencari tambahan uang saku dan rekreasi. Hal ini memperlihatkan bahwa anak jalanan yang berusia 13 sampai 15 tahun tidak merasa rendah diri karena pekerjaan mereka di jalanan sedangkan pada responden yang berusia 16 sampai 18 tahun merasa rendah diri terhadap pekerjaan mereka di jalanan dan ingin mencari pekerjaan yang lebih baik lagi. Namun konsep diri responden berusia 13 sampai 15 tahun yang cenderung positif ternyata tidak tampak pada kasus AND (15 tahun) yang mengamen hanya sampai siang karena takut bertemu teman sekolah ketika dia masih sekolah dulu. Ia mengatakan bahwa ia malu karena berhenti sekolah dan jika teman-teman sekolahnya dulu melihat dia bekerja sebagai pengamen untuk membantu keluarga.

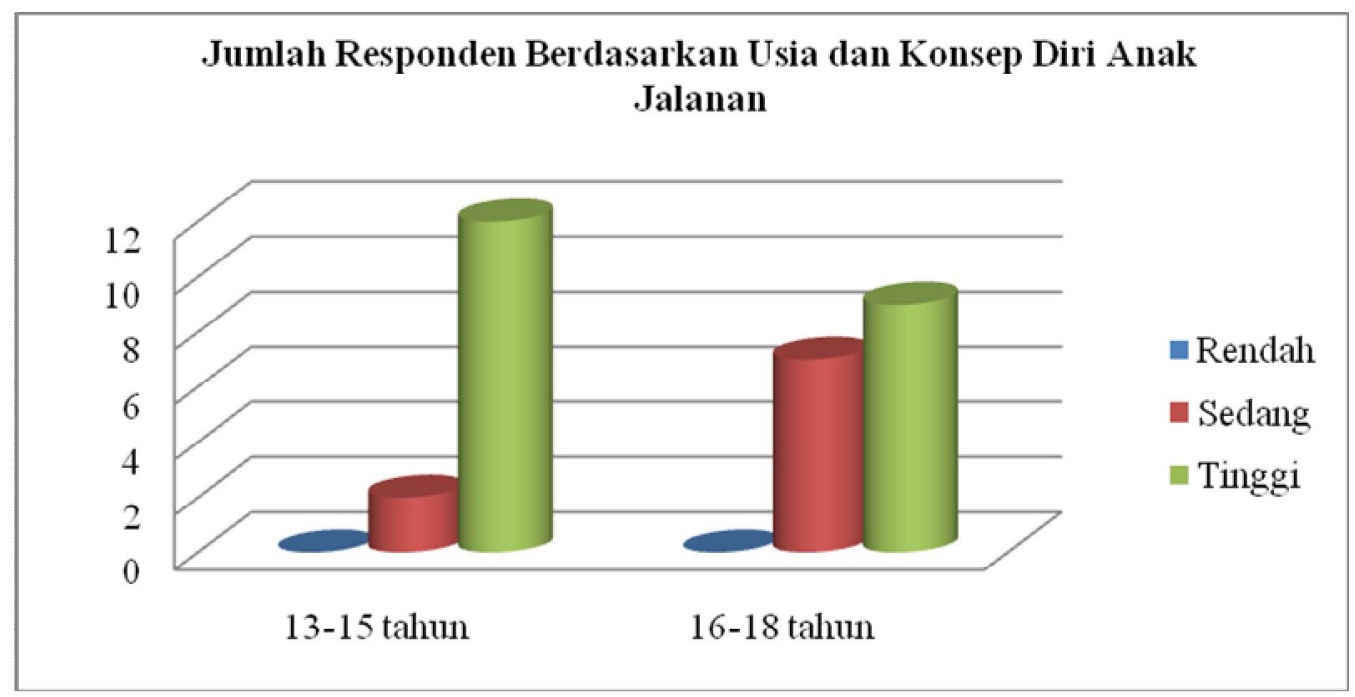

Gambar 17. Jumlah Responden Berdasarkan Usia dan Konsep Diri 
Berdasarkan Gambar 18 dapat dilihat berdasarkan jenis kelamin, konsep diri anak jalanan secara keseluruhan cenderung positif. Konsep diri positif lebih menonjol pada responden perempuan (100\%) daripada responden laki-laki $(85.71 \%)$. Responden perempuan lebih menghargai pekerjaan mereka sebagai anak jalanan dibandingkan anak jalanan laki-laki. Hal ini disebabkan responden perempuan merasa bangga walaupun mereka seorang perempuan, mereka juga bisa bekerja mencari uang untuk keluarganya. Namun pada kenyataannya konsep diri cenderung positif yang dimiliki oleh anak jalanan perempuan ternyata berbeda dengan kenyataan bahwa anak jalanan perempuan pada usia diatas 15 tahun jarang ditemukan di jalanan karena faktor rasa malu ketika usia mereka beranjak dewasa.

\section{Jumlah Responden Berdasarkan Jenis Kelamin dan Konsep}

Diri Anak Jalanan

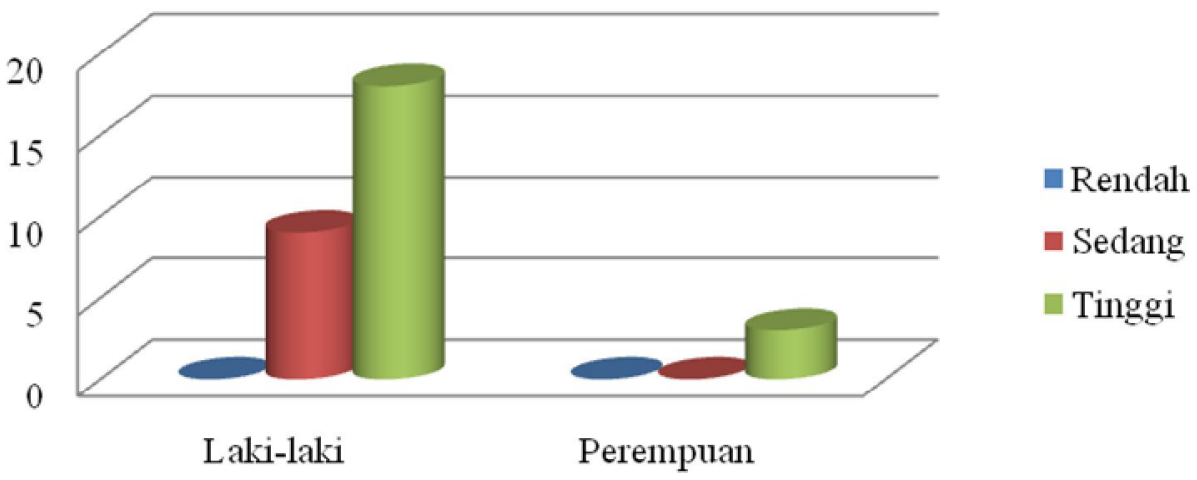

Gambar 18. Jumlah Responden Berdasarkan Jenis Kelamin dan Konsep Diri

Berdasarkan Gambar 19 dapat dilihat bahwa responden mempunyai konsep diri secara keseluruhan yang tinggi walaupun tingkat pendidikan mereka berbeda-beda. Responden yang tidak sekolah pun mempunyai konsep diri cenderung positif sama dengan responden yang pernah menerima pendidikan. Hal ini memperlihatkan bahwa tingkat pendidikan tidak menyebabkan perbedaan konsep diri anak jalanan.

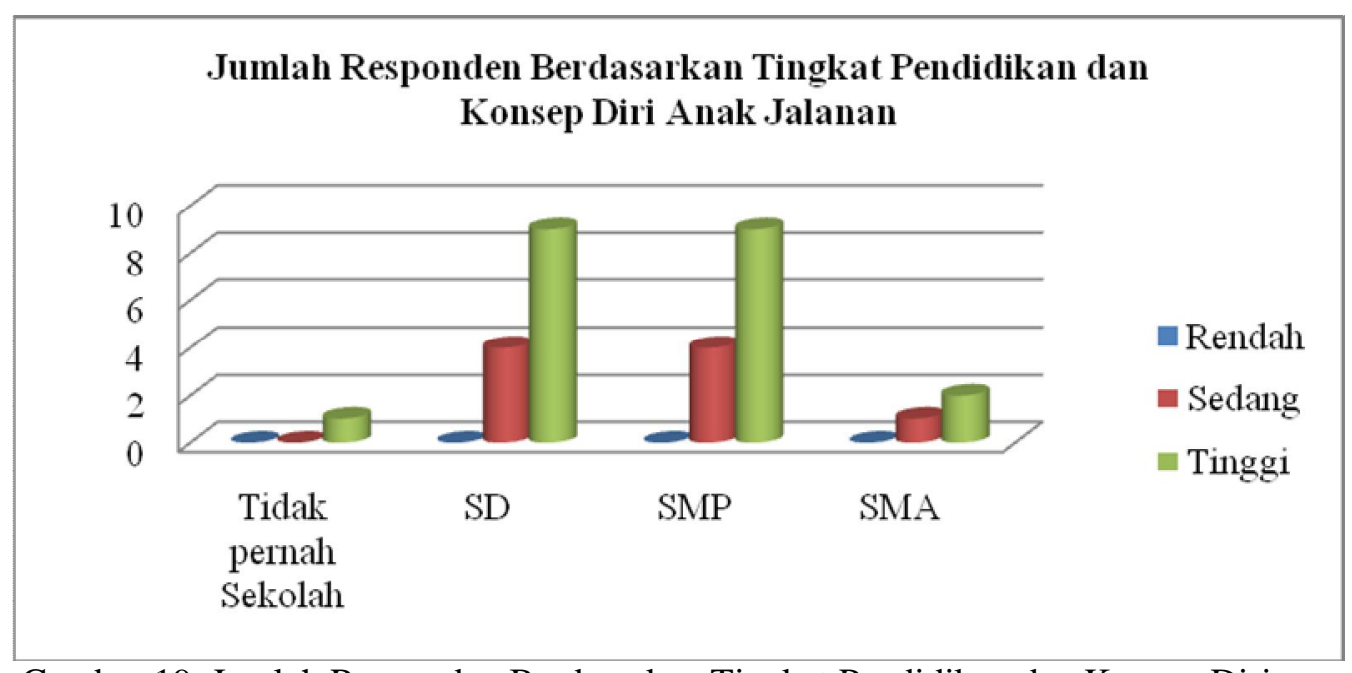

Gambar 19. Jumlah Responden Berdasarkan Tingkat Pendidikan dan Konsep Diri 
Berdasarkan Gambar 20 dapat dilihat bahwa konsep diri anak jalanan berdasarkan pekerjaan mereka cenderung positif untuk masing-masing pekerjaan. Hal ini memperlihatkan bahwa jenis pekerjaan mereka sebagai anak jalanan tidak menyebabkan perbedaan pada konsep diri yang mereka miliki karena sebagian besar responden bekerja sebagai pengamen. Responden yang bekerja sebagai pengamen mempunyai konsep diri cenderung tinggi, walaupun demikian responden yang bekerja sebagai pengamen pun masih ada yang kurang menghargai pekerjaan mereka sebagai pengamen.

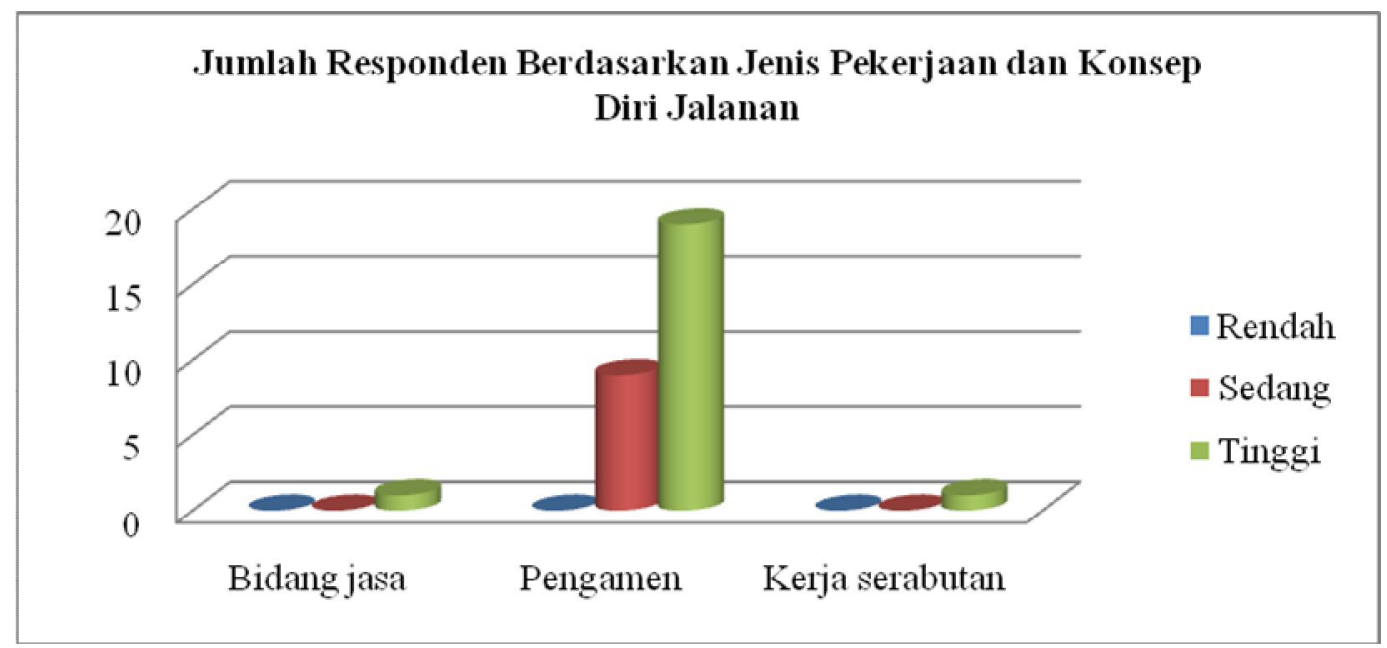

Gambar 20. Jumlah Responden Berdasarkan Jenis Pekerjaan dan Konsep Diri

Berdasarkan Gambar 21 dapat dilihat bahwa konsep diri anak jalanan berdasarkan alasan mereka turun ke jalan cenderung positif. Ada perbedaan konsep diri antara responden yang turun ke jalan karena alasan kesulitan ekonomi dengan responden yang turun ke jalan karena tambahan uang saku dan rekreasi. Sebagian besar alasan responden turun ke jalan karena tambahan uang saku dan rekreasi sehingga konsep diri mereka cenderung tinggi dibandingkan dengan responden yang turun ke jalan karena kesulitan ekonomi. Responden yang turun ke jalan karena kesulitan ekonomi lebih merasa rendah diri karena pekerjaan yang mereka lakukan di jalanan adalah untuk mencari uang. Berbeda halnya dengan responden yang turun ke jalan karena tambahan uang saku atau rekreasi, mereka tidak merasa rendah diri dengan pekerjaannya karena turun ke jalan karena pilihan mereka sendiri, bukan karena dituntut oleh keadaan ekonomi.

\section{Penutup}

Kesimpulan :

1. Pada umumnya anak jalanan adalah laki-laki dengan sebagian besar berusia 16 sampai 18 tahun dengan sebagian lainnya berusia dengan yang berusia 13 sampai 15 tahun. Pekerjaan yang banyak dilakukan anak jalanan adalah pengamen. Tingkat pendidikan responden sebagian besar hanya sampai Sekolah Dasar dan Sekolah Menengah Pertama. Tingkat sosial ekonomi keluarga responden secara keseluruhan menunjukkan mereka tergolong dalam keluarga miskin menurut kriteria BPS yaitu pendapatan di bawah Rp 
600.000,00 per bulan dan pendidikan tertinggi kepala rumah tangga hanya sampai Sekolah Dasar. Sebagian besar anak jalanan tidak pernah mengalami kekerasan di lingkungan kerjanya.

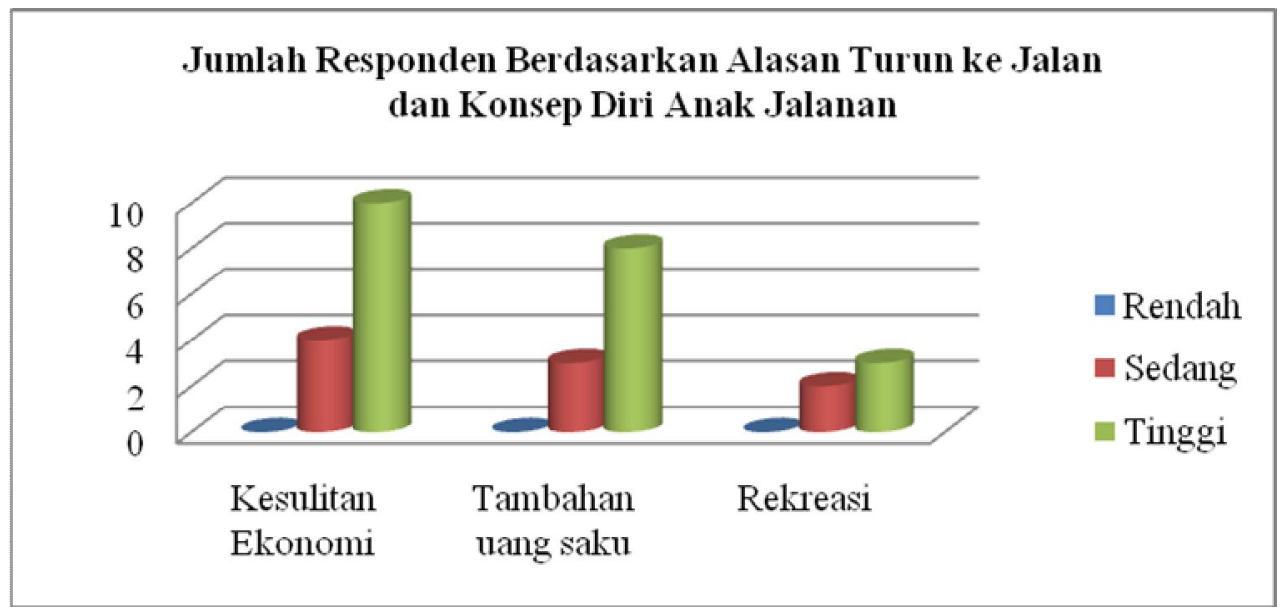

Gambar 21. Jumlah Responden Berdasarkan Alasan Turun ke Jalan dan Konsep Diri

2. Anak jalanan memiliki konsep diri cenderung positif kecuali konsep diri kestabilan emosi yang cenderung sedang.

3. Ada perbedaan antara konsep diri anak jalanan berdasarkan karakteristik sosial ekonomi anak jalanan seperti usia, jenis kelamin dan alasan turun ke jalan. Semakin bertambah usia maka konsep diri anak jalanan cenderung negatif, anak jalanan perempuan memiliki konsep diri cenderung positif dibandingkan dengan anak laki-laki, dan anak jalanan yang turun ke jalan untuk tambahan uang saku dan rekreasi mempunyai konsep diri cenderung positif dibandingkan karena alasan ekonomi. Namun perbedaan tingkat pendidikan dan jenis pekerjaan tidak menyebabkan perbedaan pada konsep diri anak jalanan karena konsep diri anak jalananan cenderung tinggi pada setiap pendidikan dan jenis pekerjaan anak jalanan cenderung sama yaitu pengamen.

4. Konsep diri anak jalanan yang cenderung positif belum nampak dalam tingkah laku keseharian mereka seperti pada saat pemilihan pekerjaan dan ketika berhubungan dengan orang lain yang tidak bekerja sebagai anak jalanan atau tidak senasib dengan mereka. Konsep diri anak jalanan ternyata tidak selalu berhubungan dengan tingkah laku dan ada faktor lainnya yang mempengaruhi seperti keterbatasan ekonomi, budaya jalanan dan rasa malas.

\section{DAFTAR PUSTAKA}

Anonim. 2003. Pada Hari Anak: Mari Dengar Suara Anak Jalanan. www.kompascetak.com. [diakses tanggal 26 Agustus 2008].

Anonim. 2004. Model Pemberdayaan Anak Jalanan Berbasis Keluarga dengan Pendekatan Multisystem.Departemen Sosial. Jakarta: UMJ Press. 
Anonim. 2006. Modul Pelayanan Sosial Anak Jalanan. Jakarta: Departemen Sosial.

Anonim. 2007. Anak Jalanan. http://www.kksp.or.id [diakses tanggal 17 November 2007].

Baron, Robert A. 2004. Psikologi Sosial. Penerjemah Ratna Djuwita dkk. Jakarta: Erlangga.

Burns, R.B. 1993. Konsep Diri: Teori, Pengukuran, Perkembangan, dan Perilaku. Penerjemah Eddy. Jakarta: Arcan.

Handoyo dkk. 2004. Profil Anak Jalanan Perempuan di Kota Semarang (Kebutuhan, Motivasi dan Aspirasinya). Fakultas Ilmu Sosial Universitas Negeri Semarang.

Hartini dkk. 2001. Profil IQ dan EQ Anak Rentan Jalanan dalam Jurnal Penelitian Dinamika Sosial volume 2 nomor 3. Fakultas Psikologi Universitas Airlangga.

Hasbiansyah, O. 1997. Konsep Diri dan Kepemimpinan KB Dalam Pembinaan Institusi Masyarakat Pedesaan (Kasus di kabupaten DT II Sumedang Propinsi Jawa Barat). Tesis. Bogor: Fakultas Pascasarjana Institut Pertanian Bogor.

Karnaji dkk. 2001. Studi Tentang Penyusunan Model Pembinaan dan Pemberdayaan Anak Jalanan dalam Jurnal Penelitian Dinamika Sosial volume 2 nomor 3. Fakultas Ilmu Sosial dan Politik. Universitas Airlangga.

Marliana, Wina. 2006. Analisis Tingkat Kekerasan pada Anak Jalanan (Kasus Anak Jalanan Binaan RPA Gessang Ghosyaari, Bogor, Jawa Barat). Skripsi. Bogor: Jurusan Sosial Ekonomi Pertanian. IPB.

Moeko, Norman. 2008. Anak Jalanan, Negara Kok Tiba-tiba Lupa? www.sinarharapan.com. [diakses tanggal 26 Agustus 2008].

Muslim, Mudaris dan Siti Mardiyati.2004. Identifikasi Problem Pribadi dan Konsep Diri Anak Jalanan yang Belajar di SD dan SMP. Fakultas Keguruan dan Ilmu Pendidikan Universitas Sebelas Maret.

Purwaningsih. 2003. Keadaan Lingkungan Keluarga dan Sosial serta Perilaku Anak Jalanan di Kota Bogor. Skripsi. Bogor: Jurusan Gizi Masyarakat dan Sumberdaya Keluarga. IPB.

Puspasari, Amaryllia. 2007. Mengukur Konsep Diri Anak. Jakarta: PT. Elex Media Komputindo.

Rakhmat, Jalaludin. 2007. Psikologi Komunikasi. Bandung: PT. Remaja Rosdakarya.

Ruslan, Rosady. 2006. Metode Penelitian Public Relation dan Komunikasi. Jakarta: PT. Raja Grafindo Persada.

Singarimbun, masri dan Sofian Effendi. 1989. Metode Penelitian Survai. Jakarta: LP3ES. 
Soe'oed, R. Diniarti. F.1999. Bunga Rampai Sosiologi Keluarga dalam T.O Ihromi (Penyunting). Jakarta: Yayasan Obor Indonesia.

Sugiharto, Sri Tjahjorini. 2001. Persepsi Anak Jalanan Terhadap Bimbingan Sosial Melalui Rumah Singgah di Kotamadya Bandung. Tesis. Bogor: Program Studi Ilmu Penyuluhan Pembangunan. IPB.

Suparlan, Supardi. 1993. Kemiskinan di Perkotaan. Jakarta: Yayasan Obor Indonesia. Jakarta.

Sutinah. 2001. Anak Jalanan Perempuan:Studi Kualitatif tentang Strategi Bertahan Hidup dan Tindak Kekerasan Seksual yang Dialami Anak Jalanan Perempuan di Kota Surabaya dalam Jurnal Penelitian Dinamika Sosial volume 2 nomor 3. Fakultas Ilmu Sosial dan Politik. Universitas Airlangga.

Syahril dkk. 2000. Kajian Terhadap Kehidupan dan Perilaku Anak-anak Jalanan Serta Dampak Sosial yang Ditimbulkannya. Fakultas Keguruan dan Ilmu Pendidikan Universitas Bengkulu.

Tauran. 2000. Studi Profil Anak Jalanan Sebagai Upaya Perumusan Model Kebijakan dalam Jurnal Administrasi Negara volume 1 nomor 1.

Yudi, Kespa Krismituhu. 2006. Analisis Peran Rumah Singgah dalam Upaya Perlindungan Anak Jalanan (kasus Rumah Singgah Rumah Kita, Kelurahan Gunung Batu, Kecamatan Bogor Barat, Kabupaten Bogor, Propinsi Jawa Barat). Skripsi. Bogor: Jurusan Sosial Ekonomi Pertanian. IPB. 